\title{
Potential viral pathogenic mechanism in human type 1 diabetes
}

\author{
Darius A. Schneider • Matthias G. von Herrath
}

Received: 29 January 2014 / Accepted: 9 June 2014 / Published online: 30 July 2014

(C) The Author(s) 2014. This article is published with open access at Springerlink.com

\begin{abstract}
In type 1 diabetes, as a result of as yet unknown triggering events, auto-aggressive $\mathrm{CD} 8^{+} \mathrm{T}$ cells, together with a significant number of other inflammatory cells, including $\mathrm{CD}^{+} \mathrm{T}$ lymphocytes with unknown specificity, infiltrate the pancreas, leading to insulitis and destruction of the insulinproducing beta cells. Type 1 diabetes is a multifactorial disease caused by an interactive combination of genetic and environmental factors. Viruses are major environmental candidates with known potential effects on specific key points in the pathogenesis of type 1 diabetes and recent findings seem to confirm this presumption. However, we still lack wellgrounded mechanistic explanations for how exactly viruses may influence type 1 diabetes aetiology. In this review we provide a summary of experimentally defined viral mechanisms potentially involved in the ontology of type 1 diabetes and discuss some novel hypotheses of how viruses may affect the initiation and natural history of the disease.
\end{abstract}

Keywords Autoimmune $\cdot$ Enterovirus $\cdot$ Environmental factors $\cdot$ Humans $\cdot$ Insulitis $\cdot$ Type 1 diabetes $\cdot$ Viruses
Abbreviations
CVB Group B coxsackievirus
HERV Human endogenous retrovirus
nPOD Network of Pancreatic Organ Donors

D. A. Schneider · M. G. von Herrath $(\bowtie)$

La Jolla Institute for Allergy and Immunology, 9420 Athena Circle,

La Jolla, CA 92037, USA

e-mail: Matthias@liai.org

D. A. Schneider

Department of Medicine, UC San Diego, La Jolla, CA, USA

M. G. von Herrath

Novo Nordisk Type 1 Diabetes Research Center,

Seattle, WA 98109, USA
PBMC Peripheral blood mononuclear cell

PLN Pancreatic lymph node

\section{Introduction}

While there is undoubtedly evidence for a genetic basis of type 1 diabetes, especially with regard to permissive HLA class II genotypes, many features of this disease have to be attributed to environmental factors, specifically, (1) the annual increase in type 1 diabetes incidence, currently estimated to be $3 \%$ [1]; (2) the strong heterogeneity of its geographical distribution, which is subject to considerable regional gradients [2]; (3) the fact that the incidence rate in first-generation offspring of immigrants is the same as that in the new home country $[3,4]$.

In animal models of diabetes the established role of innate inflammation in the insulitic process [5-7] and the increasing evidence supporting the contribution of viral infections to a proinflammatory islet milieu [8-10] strongly suggest that viruses may contribute to beta cell damage and dysfunction. The evidence for the presence of similar mechanisms in humans is still circumstantial [11-13]; however, the insights gained from animal studies imply that innate immunity is an important component of the pathogenesis of type 1 diabetes. Lately, novel developments in analysis techniques, as well as access to organ libraries, such as the Network of Pancreatic Organ Donors (nPOD, www.jdrfnpod.org) in the USA or the collection of Foulis et al [14] in the UK will be instrumental in allowing us to link the presence of these environmental determinants to the highly complex histopathological features of type 1 diabetes.

In this review we will analyse how viral infections can account for these highly complex scenarios. 


\section{Hallmarks of type 1 diabetes pathogenesis}

Type 1 diabetes results from the selective and progressive destruction of insulin-producing cells by autoreactive $\mathrm{CD} 8^{+}$ $\mathrm{T}$ cells [15] and a variable number of bystander $\mathrm{CD}^{+} \mathrm{T}$ cells $[16,17]$. The presence of anti-islet cell antigen autoantibodies and a predominantly lymphocytic infiltrate of the islets (insulitis) including $\mathrm{CD}^{+} \mathrm{T}$ cells antigen-specific for beta cell antigens [15] are regarded as proof of the autoimmune aetiology of the disease [14, 18, 19] (Fig. 1).

The nature of early disease may be cyclical and relapsing-remitting

Based on the very character of the most prolific feature of type 1 diabetes - insulitis - it is thought that early disease might involve cycling between remission and relapse [20]. In spite of being considered a hallmark of type 1 diabetes, the occurrence of insulitis is heterogeneous and often elusive. When combining all 215 cases of type 1 diabetes for which minimal clinical and histopathological data exist, it can be estimated that in young type 1 diabetes patients $<14$ years old, insulitis occurs in $73 \%$ of those with a diabetes duration of $<1$ month, in $60 \%$ of those with a diabetes duration of $>1$ month but $<1$ year, and in $4 \%$ of patients with a diabetes duration of $>1$ year. In donors $>15$ years of age, insulitis was only found in $29 \%$ of those with acute-onset diabetes [21, 22]. In autoantibody-positive donors, the numbers were far lower: only two out of 62 autoantibody-positive, non- diabetic organ donors showed insulitis [23]. Furthermore, insulitis seems to follow a lobular pattern rather than affecting all islets in a given pancreas [14, 24]. If we regard insulitis as a conditio sine qua non for the later development of type 1 diabetes, given that insulitis is not observed in all cases positive for autoantibodies, we have to consider the possibility that the nature of early disease is remitting-relapsing, with phases of intense inflammation alternating with quiescent phases.

The distribution of the disease is not homogeneous

Contrary to what we would expect in a stochastic development, the distribution of the immune process in type 1 diabetes is inhomogeneous and lobular, with pancreatic lobules that are affected, and lobules that are not [14, 15, 19, 24, 25]. This pattern is also seen in the map of inflammatory cytokine production [26]. Furthermore, the exocrine pancreas is often smaller $[27,28]$ and mildly infiltrated, and insulitis is not as prominent as usually seen in animal models, e.g. the NOD mouse [22, 29].

The presence, temporal pattern, cellular composition and distribution of the inflammatory infiltrate [20] are highly variable [30], which is mirrored in the high variability of the preclinical period preceding diabetes [31].

Taken together, we can envision the following picture: an underlying inflammation of the pancreas, caused by an as yet unknown initial event and characterised by a rather discrete lymphocytic infiltrate and the upregulation of MHC I on some beta cells [15], could represent a fertile soil [32, 33] for a

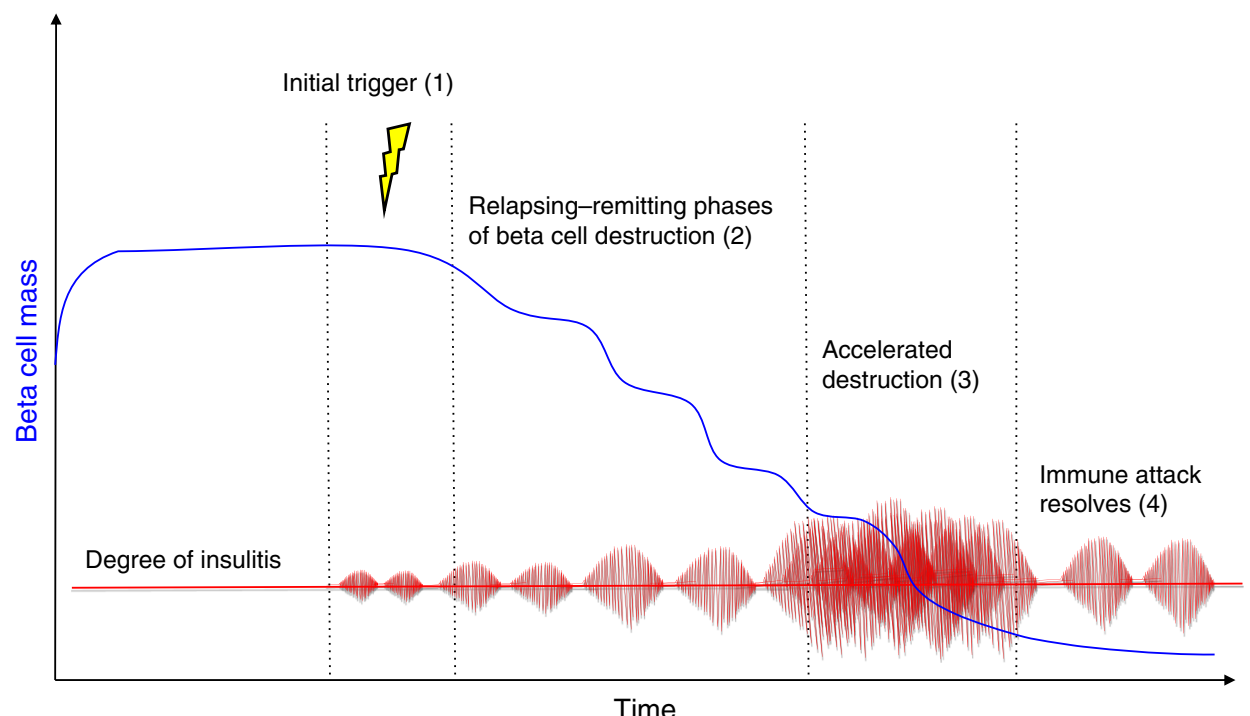

Fig. 1 Timeline of development of type 1 diabetes. In genetically susceptible individuals, an as yet unknown environmental trigger (1) causes an underlying inflammation of the pancreas that is characterised by a rather discrete lymphocytic infiltrate and the upregulation of MHC I on some beta cells (insulitis). This represents a fertile soil for a complex interplay between T-effector and T-regulatory cells, eventually favouring the $\mathrm{CD}^{+}$T-effector-mediated attack, causing a scenario of concomitant beta cell destruction and enhanced proliferation (2). The sequential appearance and spreading of antigenic determinants leads to the enhancement of the immune response (3) and feeds a vicious cycle. As soon as the vast majority of beta cells is destroyed, the immune reaction slows down (4), yet some of its features (MHC I upregulation) remain detectable for a long time, probably fuelled by the few remaining beta cells. Pathophysiologically, phases (2) and (3) coincide with the transition from normoinsulinaemia to hypoinsulinaemia and finally to the loss of detectable C-peptide levels 
complex interplay between effector and regulatory $\mathrm{T}$ cells, eventually favouring $\mathrm{CD} 8^{+}$effector $\mathrm{T}$ cells that attack the beta cells. This leads to a scenario of concomitant beta cell destruction and enhanced proliferation, with the sequential appearance and spreading of antigenic determinants and the enhancement of the immune response [34]. As recent works suggest [35], the underlying inflammatory state of the pancreas might initially involve the exocrine pancreas, prior to the induction of autoimmunity. As soon as the latter is triggered, a vicious cycle is born.

\section{How can the histopathological hallmarks of diabetes be explained by viral infection?}

In spite of a plethora of studies (see Table 1 for an overview of important studies), we are still lacking a clearly established, causal link between viral infection or presence and the development of autoimmunity or progression to diabetes, yet the histopathological hallmarks of diabetes can be elegantly explained as effects of viral interference:

(1) The heterogeneous, possibly relapsing-remitting insulitis, with upregulation of MHC class I molecules on most islets, which persists for years irrespective of the functional status of the islets, can be caused by interferons or other factors secreted from cells infected by virus.

(2) Enteroviruses have been shown to have a strong pancreotropism - severe islet damage has been demonstrated in fatal group B coxsackievirus (CVB) infection cases [36], human islets show strong expression of the coxsackie virus and adenovirus receptor (CAR) [37] and beta cells are permissive for enterovirus in vitro [38]. Also, human peripheral blood mononuclear cells (PBMCs) experimentally infected with CVB4 show enhanced production of proinflammatory cytokines such as TNF- $\alpha$ and IL-6 [39].

(3) It has recently been shown that the inflammatory state of the pancreas can be explained by direct or indirect viral effects $[40,41]$.

\section{Mechanisms of viral involvement in type 1 diabetes aetiology}

When we discuss viral infections, we have to consider viral infections of the pancreatic beta cells as well as of those cells adjacent to the beta cells (acinar cells, endothelial cells, neurons) or of cells at a remote location, such as dendritic cells, leading to presentation of cross-reacting epitopes, or of gut cells, leading to increased gut permeability and the presentation of cross-reacting antigens in the pancreatic lymph nodes, where pancreatic and gut lymphatic drainage intersect [42]. From a chronological point of view, viral infections can be either (1) acute, (2) exacerbated chronic infections, (3) reactivated persistent, quiescent viruses (e.g. Herpesviridae), or (4) represent the restoration of pathogenicity of viral segments that had long been integrated in the human genome, such as human retroviruses.

Infection of beta cells

Infection of beta cells with subsequent damage and release of antigens, as well as release of interferons and involvement of both innate and adaptive immune system, is the mechanism by which enteroviruses are thought to be involved in the pathogenesis of type 1 diabetes. This is, by far, the mechanism that has been investigated to the largest extent and has dominated scientific debate on this topic for many years.

Acute infection Acute infection is linked with severe damage of the beta cells and rapid progression towards fulminant diabetes. This is the case in fulminant type 1 diabetes, where an association with direct enteroviral infection has been discussed in case reports [43] and where autoimmunity is not primarily involved. Here we may also add examples of enterovirusinduced diabetes in animals: cattle after infection with the foot and mouth virus [44], voles after infection with Ljungan virus [45], rats after infection with the Kilham virus [46], as well as higher non-human primates infected with CVB4 virus [47]. Especially in the case of CVB4, we suspect considerable differences in viral strain-specific pancreotropism.

Chronic infection Chronic, rather slow and persistent type of infection with stimulation of resting beta-cell-antigen-specific $\mathrm{T}$ lymphocytes is thought to be the link between CVB infections and the induction of autoimmunity and/or progression to diabetes and leads to subtle changes in the beta cells. These changes may involve the induction of endoplasmic reticulum stress [48] or mutations in tyrosine kinase 2 (TYK2) or similar proteins leading to beta-cell-specific suppression of cytokine responses including interferon [49], which leads to high sensitivity to CVB4 infection [50] or other changes in beta cell metabolism which, in turn, lead to local inflammation and tissue damage with the slow release of sequestered islet antigen and stimulation of quiescent, beta-cell-antigen-specific $\mathrm{T}$ (memory) cells.

Infection of cells adjacent to beta cells

Exocrine pancreatic cells The exocrine pancreas is targeted by a myriad of different viruses, and many of them have been associated with type 1 diabetes either in humans or in animal models: measles virus, congenital rubella virus, mumps virus, cytomegalovirus [51], or even viruses with high penetration of 
Table 1 Synopsis of important studies addressing viral causes of type 1 diabetes

\begin{tabular}{|c|c|c|}
\hline Reference & Virus & Main message \\
\hline Rasmussen et al, 2011 [90] & Respiratory viruses & Respiratory infections more common in children who later progress to type 1 diabetes. \\
\hline Beyerlein et al, 2013 [91] & $\begin{array}{l}\text { Respiratory viruses, } \\
\text { not classified }\end{array}$ & $\begin{array}{l}\text { Increased hazard ratio of islet autoantibody seroconversion is associated with respiratory } \\
\text { infections during the first } 6 \text { months of life. }\end{array}$ \\
\hline Gale, 2008 [92] & Rubella & Congenital rubella may predispose to subsequent autoimmunity but existing studies are weak. \\
\hline Viskari et al, 2003 [93] & Rubella & $\begin{array}{l}\text { No evidence of increased frequency of markers for humoral beta cell autoimmunity in } \\
\text { patients with congenital rubella syndrome. }\end{array}$ \\
\hline Green et al, 2004 [94] & CVB & $\begin{array}{l}\text { Review of } 26 \text { case-control studies: no convincing evidence for or against an association } \\
\text { between CVB infection and type } 1 \text { diabetes. }\end{array}$ \\
\hline Stene et al, 2010 [65] & EV & $\begin{array}{l}\text { Progression from islet autoimmunity to type } 1 \text { diabetes may increase after an EV infection } \\
\text { characterised by the presence of viral RNA in blood. }\end{array}$ \\
\hline Tapia et al, 2011 [95] & EV & No support for faecal shedding of enteroviral RNA as major predictor of advanced islet autoimmunity. \\
\hline Yeung et al, 2011 [96] & EV & $\begin{array}{l}\text { Clinically significant association between EV infection, detected with molecular methods, } \\
\text { and autoimmunity/type } 1 \text { diabetes. }\end{array}$ \\
\hline Salur et al, 2011 [97] & EV & $\begin{array}{l}\text { Nested case-control study where all case children have progressed to type } 1 \text { diabetes. EV } \\
\text { RNA-positive samples were more frequent among the cases than among the controls. }\end{array}$ \\
\hline Oikarinen et al, 2012 [98] & EV & $\begin{array}{l}\text { Large proportion of type } 1 \text { diabetes patients have prolonged/persistent EV infection } \\
\text { associated with an inflammation process in gut mucosa. }\end{array}$ \\
\hline Mercalli et al, 2012 [99] & EV & $\begin{array}{l}\text { Small intestine biopsy samples from } 25 \text { individuals at different stages of type } 1 \text { diabetes, } \\
21 \text { controls and } 27 \text { individuals with coeliac disease analysed for the presence of EV RNA } \\
\text { by in situ hybridisation and RT-PCR. Prolonged/persistent EV infections in gut mucosa } \\
\text { are not common in patients with type } 1 \text { diabetes. }\end{array}$ \\
\hline Viskari et al, 2000 [100] & EV & $\begin{array}{l}\text { The rapid decrease in EV infection frequency in Finland may explain the increasing incidence } \\
\text { of type } 1 \text { diabetes. }\end{array}$ \\
\hline Roivainen et al, 2002 [101] & EV & $\begin{array}{l}\text { Patterns and consequences of EV infections investigated in cultured adult human isolated islets. } \\
\text { The capacity of EV to kill human beta cells or impair their function is not solely defined by } \\
\text { the serotype, but also by as yet unidentified characteristics of the virus strain involved. }\end{array}$ \\
\hline Viskari et al, 2004 [102] & EV & $\begin{array}{l}\text { EV antibodies less frequent in countries with high diabetes incidence compared with countries } \\
\text { with low diabetes incidence. }\end{array}$ \\
\hline Viskari et al, 2005 [103] & EV & $\begin{array}{l}\text { Maternal EV antibodies analysed from serum samples taken from pregnant women between } \\
1983 \text { and } 2001 \text { in Finland and Sweden. A low frequency of EV infection in the background } \\
\text { population increases the susceptibility of young children to the diabetogenic effect of EV. }\end{array}$ \\
\hline Richardson et al, 2009 [104] & EV & $\begin{array}{l}\text { EV capsid protein VP1 is commonly found in the islets of recent-onset type } 1 \text { diabetic patients, } \\
\text { but only rarely in normal paediatric controls. }\end{array}$ \\
\hline Gamble et al, 1973 [105] & CVB4 & $\begin{array}{l}\text { Antibody to CVB4 virus more often found in diabetic patients than in controls, particularly } \\
\text { in the } 10-19 \text { year age group. }\end{array}$ \\
\hline Gamble et al, 1969 [106] & EV & $\begin{array}{l}\text { In patients with recent-onset diabetes, no evidence was found of any excess of antibodies } \\
\text { to mumps virus or certain common respiratory viruses. However, those diabetics patients who } \\
\text { developed insulin dependence within } 3 \text { months of onset were found to have higher } \\
\text { antibody titres to CVB4. }\end{array}$ \\
\hline Dotta et al, 2007 [107] & EV & $\begin{array}{l}\text { Pancreatic tissue from six type } 1 \text { diabetic and } 26 \text { control organ donors analysed via } \\
\text { immunohistochemistry, electron microscopy, whole-genome ex vivo nucleotide sequencing, } \\
\text { cell culture and immunological studies. CVB4 found in specimens from three of the six } \\
\text { diabetic patients. }\end{array}$ \\
\hline Laitinen et al, 2013 [62] & CVB1, B3, B6 & $\begin{array}{l}183 \text { children who persistently tested positive for at least two diabetes-predictive autoantibodies } \\
\text { and } 366 \text { autoantibody-negative matched control children. CVB1 was associated with an } \\
\text { increased risk of beta cell autoimmunity. This risk was strongest when infection occurred a few } \\
\text { months before autoantibodies appeared and was attenuated by the presence of maternal antibodies } \\
\text { against the virus. Two other coxsackieviruses, B3 and B6, were associated with a reduced risk. }\end{array}$ \\
\hline Oikarinen et al, 2014 [61] & CVB1 & $\begin{array}{l}249 \text { children with newly diagnosed type } 1 \text { diabetes and } 249 \text { control children matched according } \\
\text { to sampling time, sex, age and country recruited in Finland, Sweden, England, France and } \\
\text { Greece between } 2001 \text { and } 2005 \text { (mean age } 9 \text { years; } 55 \% \text { male). Antibodies against CVB1 } \\
\text { were more frequent among diabetic children than among control children. }\end{array}$ \\
\hline Cabrera-Rode et al, 2003 [108] & Echovirus 16 & $\begin{array}{l}\text { The occurrence of a large-scale echovirus } 16 \text { epidemic was associated with the appearance } \\
\text { of humoral autoimmune markers of type } 1 \text { diabetes. Echovirus } 16 \text { infection might be capable } \\
\text { of inducing a process of autoimmune beta cell damage. }\end{array}$ \\
\hline
\end{tabular}

$\mathrm{EV}$, enterovirus 
the population, examples of which include influenza A [52] and B [53]. To date, however, we lack a direct causative link between viraemia and the development of autoantibodies or the transition from autoantibody positivity to diabetes, as a recent analysis of cases from The Environmental Determinants of Diabetes in the Young (TEDDY) study has shown [54]. We can envision that a viral infection of acinar cells and the subsequent activation of the innate immune response may be responsible for the inflammatory state that we and others have noticed in the pancreas, which sets the stage for the development of autoimmunity (self meets inflammation). If correct, this might support the application of antiinflammatory therapies at onset of diabetes (in conjunction with other tolerogenic approaches).

Neuronal cells adjacent to beta cells The pancreatic islet is a highly innervated and vascularised mini organ, and viral infections can occur in any of the cell types surrounding the actual beta cell. The recent observation in the mouse that the first structures to be prone to the autoimmune attack do not necessarily have to be the beta cells themselves, but can be sensory neuronal cells innervating the islet [55], prompted us to investigate the role of neurotropic viruses in the induction of autoimmunity in human samples. Reoviridae (like rotavirus) have long been found to induce autoimmune biliary atresia and to infect the plexus myentericus and the nervus vagus and persist in neuroenteric structures, and ciclosporin was shown to inhibit rotavirus replication and to restore interferon beta signalling pathway both in vitro and in vivo [56]. This hypothesis would elegantly account for the lobular spreading and the temporal pattern of diabetes, and also for the methodical difficulties encountered in identifying viral traces in islets, since neurotropic viruses would reside in dorsal root ganglia when quiescent. This concept, corroborated by the fact that remote infections of neurons innervating the myenteric plexus with human herpesvirus 6 (HHV6) may lead to increased gut inflammation and, subsequently, permeability [57] offers a new avenue for research.

\section{Infection of cells at remote locations}

Infection of dendritic cells by viruses carrying cross-reactive epitopes: the concept of molecular mimicry This mechanism has been extensively discussed elsewhere [58, 59] and is based on the observation that a single $\mathrm{T}$ cell receptor can recognise quite distinct but structurally related peptides from multiple pathogens [60]. Directly linked to type 1 diabetes triggering was the observation that one amino acid sequence from GAD65 (PEVKEK) is highly conserved in CVB4 isolates as well as in different viruses of the subgroup of CVB-like enteroviruses.

Coxsackie viruses have long been suspected to be the main culprits in the induction of autoimmunity in the aetiology of type 1 diabetes, and large studies of young children have substantiated these hypotheses: antibodies against CVB1 are more frequent among diabetic children than in control children, while other CVB types do not differ between the groups [61], and CVB1 is associated with an increased risk of beta cell autoimmunity [62]. This risk is strongest when infection occurs a few months before the appearance of autoantibodies and is attenuated by the presence of maternal antibodies against the virus. Two other CVB types, B3 and B6, are associated with a reduced risk, with an interaction pattern suggesting immunological cross-protection against CVB1 [62].

Besides enterovirus, other viruses known to contain crossreactive epitopes (rubellavirus, rotavirus) have often been identified during the onset of diabetes [63-65] or have been shown to facilitate the appearance of autoantibodies, as in the case of certain strains of echovirus [66].

Pivotal players in these scenarios are the dendritic cells, which are known to initiate the immune response by potent expression of co-stimulatory molecules. The observation that reduced early virus replication blunted $\mathrm{CD} 8^{+} \mathrm{T}$ cell priming and prevented the onset of diabetes in a model of virusinduced diabetes led to the discovery that early virus replication in dendritic cells is essential to disrupt immune tolerance and that this process is dependent on expression of ubiquitin specific peptidase 18 (USP18), an inhibitor of the IFN $\gamma$ pathway [67]. In this study, early viral replication was only possible in dendritic cells, in which the IFN pathway was downregulated, which is also an important prerequisite for the induction of autoimmunity.

Infection of gut cells and changes in gut permeability This is a speculative thought based on the observation that many viral infections of the gut lead to increased gut permeability, with novel antigens being presented in draining lymph nodes. Bearing in mind that the lower gut and the pancreatic lymphatic drainage intersect in the pancreatic lymph nodes (PLNs) [42], one can easily envision a scenario in which auto-reactive $\mathrm{CD} 8^{+}$cells are primed with cross-reactive epitopes occurring in the PLNs as the result of increased gut permeability. Another possibility is that changes in the microbiome are induced by viral infections. For example, it is known that, in particular, bacteriophage, i.e. viruses that infect bacteria of the human gut microbiome, show high variation as a result of changes in diet, hormonal balance or even climate changes [68] - much more than the infected bacteria themselves. Recent findings suggest that altering certain bacterial populations present in the gut can lead to an inflammatory state associated with Th1/Th17 polarisation and, thus, to autoimmunity [69]. Therefore, since bacteriophage seem to be important determinants of the gut microbiome, the differences in diabetes incidence between monozygotic twins, or between inhabitants, different regions 
[2], or between immigrants and the first-generation of offsprings from those immigrants $[3,4]$ can be explained by differences in the gut virome.

\section{Other mechanisms potentially involved in virally facilitated initiation or acceleration of autoimmunity}

\section{Reactivation of endogenous HERV}

Human endogenous retroviruses (HERVs) [70] are fossil viruses that began to be integrated into the human genome some $30-40$ million years ago and now make up $8 \%$ of the genome. HERVs may be triggers of autoimmune disease by provision of a source of novel viral genes for recombination with exogenous viruses, by immune dysregulation or by super-antigen motifs. HERV infection has been shown to trigger autoimmune rheumatic disease, and the resultant inflammation observed could lead to elevated HERV expression [70]. The potential role of HERV in diabetes has not been deciphered yet, but we will likely see more work done in this field in the upcoming years.

\section{Activation of polyclonal $\mathrm{T}$ cells}

Recent observations in a virus-based diabetes models of the mouse $[17,71,72]$ have taught us that beta-cell-antigenspecific $T$ cells can recruit a high number of non-beta-cellantigen-specific bystander $\mathrm{T}$ cells that add to the destruction of beta cells (more than $98 \%$ of infiltrating CD8 cells in the rat insulin promoter-lymphocytic choriomeningitis virus (RIP-LCMV) model are not viral-antigen-specific [17]). From this point of view, any viral infection of pancreatic structures can lead to an accumulation of activated T cells in the immediate vicinity of beta cells, which might significantly affect their health and function.

Viral transformation of autoreactive B cells

Polyreactivity can arise as a result of random rearrangement of Ig genes during B cell development [73], yet most of the autoreactive B cells are eliminated via clonal deletion, anergy or receptor editing [74]. However, cross-reactivity is a common serological feature of certain viral infections in humans (HIV [75], Epstein-Barr virus [76], hepatitis A virus [77], hepatitis $C$ virus [78]) and persisting viral infection have long been shown to lead to polyclonal B cell activation [79]. We have yet to find an explanation of how these phenomena are accompanied by a mechanism for affinity maturation of these clonal products, which would be the crucial prerequisite for autoimmunity, but recent observations have provided new, exciting insights $[80,81]$.
Can viral infections afford protection against diabetes?

In the NOD mouse, we and others have shown that infection with CVB can abrogate the development of type 1 diabetes [82] when given at a very early time point. Mechanistic explanations comprise an upregulation of programmed death ligand 1 (PD-L1) and TNF- $\alpha$ production, as well as a bystander activation of protective regulatory $\mathrm{T}$ cells. Furthermore, transferring a small number of regulatory $\mathrm{T}$ cells (that would not normally be sufficient to afford protection) from a NOD mouse that has previously been infected with CVB3 to another NOD mouse will protect the latter from developing type 1 diabetes; thus, the viral infection may invigorate the regulatory $\mathrm{T}$ cell compartment [82]. These enhancing effects upon polyclonal Tregs are mainly elicited through TLR2 [83].

Conclusive information in humans is lacking. A prerequisite for viral infection-associated induction of autoimmunity is the ability of the viral strain to damage islet cells and to induce proinflammatory innate immune responses within the infected islets. Thus, the presence of certain viral strains that lack this ability (as is the case with CVB6 or echovirus E4 [66]) may protect the host from infections with their beta cytotoxic counterparts. Hence, there might be a protective mechanism at play, similar to the one facilitated by the commensal bacteria present in the gut, and further work is necessary to ascertain this.

Besides strain specificities, infection dose and viral replication rate may also determine whether a given infection is protective or promoting with regard to the initiation of autoimmunity [84]. These differential effects may be explained by differences in the virus-mediated upregulation of inflammatory cytokine production, since the potentiation of cytokine production in infected human PBMCs has been shown to be associated to CVB4 infectivity. Hence, a vaccine covering all major CVB strains, for example, might lower the severity of infections and transform a promoting into a protective infection type.

\section{Conclusions}

When cumulative environmental determinants facilitate the development of autoimmunity, virus infections may serve as one of many risk factors. While many associations have been found between type 1 diabetes and viruses, mostly enteroviruses, we do not have a clear picture overall. It remains to be determined how often viruses induce autoimmunity or beta cell destruction and how often they accelerate the progression from autoimmunity to disease.

Attempts to directly demonstrate the presence of viral peptides within beta cells of diabetic patients have led to controversial results. In spite of several successful reports [85], a recently published work by Korsgren and colleagues 
[86] has reported that the particular mouse monoclonal antibody (clone 5D8/1) used to detect the viral capsid protein VP1 strongly cross-reacts with human mitochondrial peptides, especially in situations of mitochondrial stress. Thus, in addition to the detection of viruses by antibodies, we will need to demonstrate the presence of their genome by in situ hybridisation and, in the ideal case, associate these findings with local pathology present in the human pancreas, such as the lobular MHC class I upregulation in whole islets - indeed, such effort is already being carried out by the nPOD viral consortium (nPOD-V) [87] and should provide more conclusive results within the next year. The recently founded nPOD-V group represents an unparalleled collaborative setting, highly committed to answer the question of viral implication in diabetes and we are looking forward to the results.

From a mechanistic point of view, viral infections can very well explain many of the hallmark features of early diabetes, the difficult task is now to focus on novel methodologies that are capable of dissecting the few existing specimens in depth and establish conclusive associations between pathology and viral presence or traces thereof. The breakdown of tolerance towards autoantigens could indeed represent a derailment of physiological autoreactivity and may thus be a secondary phenomenon caused by chronic stimuli. One of these stimuli might be chronic viral infections, but we have to bear in mind that there are other chronic states, such as the recently described regurgitation of duodenal bacteria into the common pancreatic duct [88] or various forms of stress [89], that can serve as stimuli in this very context.

For the future, we need considerably more studies on human specimens to address crucial questions in the quest for the causes of type 1 diabetes: What is the exact phenotype and antigen specificity of immune cells infiltrating the islets? What is the exact involvement of the innate immune systems in human type 1 diabetes? What is the exact time point for the occurrence of insulitis? What methods are most suitable to detect viral causes of autoimmunity and how can we avoid causality traps in complex biological systems? What changes within the islets may lead to their own demise even before autoimmunity is involved?

Acknowledgements We thank M. C. Nussenzweig (Howard Hughes Medical Institute, New York, NY, USA) for insightful discussions. We acknowledge Englue (http://www.englue.com) for donating artificial intelligence-based technology to data-mine articles contained in PubMed Central.

Duality of interest statement The authors declare that there is no duality of interest associated with the manuscript.

Contribution statement Both authors were responsible for the conception and design of the manuscript as well as for revising it critically for important intellectual content. DAS drafted and wrote the manuscript. Both authors approved the final version of the manuscript.
Open Access This article is distributed under the terms of the Creative Commons Attribution License which permits any use, distribution, and reproduction in any medium, provided the original author(s) and the source are credited.

\section{References}

1. Karvonen M, Viik-Kajander M, Moltchanova E, Libman I, LaPorte R, Tuomilehto J (2000) Incidence of childhood type 1 diabetes worldwide. Diabetes Mondiale (DiaMond) Project Group. Diabetes Care 23: $1516-1526$

2. Kondrashova A, Reunanen A, Romanov A et al (2005) A six-fold gradient in the incidence of type 1 diabetes at the eastern border of Finland. Ann Med 37:67-72

3. Bodansky HJ, Staines A, Stephenson C, Haigh D, Cartwright R (1992) Evidence for an environmental effect in the aetiology of insulin dependent diabetes in a transmigratory population. BMJ 304:1020-1022

4. Delli AJ, Lindblad B, Carlsson A et al (2010) Type 1 diabetes patients born to immigrants to Sweden increase their native diabetes risk and differ from Swedish patients in HLA types and islet autoantibodies. Pediatr Diabetes 11:513-520

5. Lang KS, Recher M, Junt T et al (2005) Toll-like receptor engagement converts T-cell autoreactivity into overt autoimmune disease. Nat Med 11:138-145

6. Rhode A, Pauza ME, Barral AM et al (2005) Islet-specific expression of CXCL10 causes spontaneous islet infiltration and accelerates diabetes development. J Immunol 175:3516-3524

7. Frigerio S, Junt T, Lu B et al (2002) Beta cells are responsible for CXCR3-mediated T-cell infiltration in insulitis. Nat Med 8:1414 1420

8. von Herrath M, Holz A (1997) Pathological changes in the islet milieu precede infiltration of islets and destruction of beta-cells by autoreactive lymphocytes in a transgenic model of virus-induced IDDM. J Autoimmun 10:231-238

9. Wolter TR, Wong R, Sarkar SA, Zipris D (2009) DNA microarray analysis for the identification of innate immune pathways implicated in virus-induced autoimmune diabetes. Clin Immunol 132:103115

10. Nair A, Wolter TR, Meyers AJ, Zipris D (2008) Innate immune pathways in virus-induced autoimmune diabetes. Ann N Y Acad Sci 1150:139-142

11. Foulis AK (2008) Pancreatic pathology in type 1 diabetes in human. Novartis Found Symp 292:2-13, discussion 13-18, 122-129, 202 203

12. Roep BO, Kleijwegt FS, van Halteren AG et al (2010) Islet inflammation and CXCL10 in recent-onset type 1 diabetes. Clin Exp Immunol 159:338-343

13. Kallionpää H, Elo LL, Laajala E et al (2014) Innate immune activity is detected prior to seroconversion in children with HLA-conferred type 1 diabetes susceptibility. Diabetes 63:2402-2414

14. Foulis AK, Liddle CN, Farquharson MA, Richmond JA, Weir RS (1986) The histopathology of the pancreas in type 1 (insulindependent) diabetes mellitus: a 25-year review of deaths in patients under 20 years of age in the United Kingdom. Diabetologia 29:267274

15. Coppieters KT, Dotta F, Amirian N et al (2012) Demonstration of islet-autoreactive CD8 T cells in insulitic lesions from recent onset and long-term type 1 diabetes patients. J Exp Med 209:51-60

16. Savinov AY, Wong FS, Stonebraker AC, Chervonsky AV (2003) Presentation of antigen by endothelial cells and chemoattraction are required for homing of insulin-specific $\mathrm{CD} 8^{+} \mathrm{T}$ cells. J Exp Med 197:643-656 
17. Chabot S, Fakhfakh A, Beland K et al (2012) Mouse liverspecific $\mathrm{CD}^{+}$T-cells encounter their cognate antigen and acquire capacity to destroy target hepatocytes. J Autoimmun 42:19-28

18. Gepts W (1965) Pathologic anatomy of the pancreas in juvenile diabetes mellitus. Diabetes 14:619-633

19. Eisenbarth GS (1986) Type I diabetes mellitus. A chronic autoimmune disease. N Engl J Med 314:1360-1368

20. Campbell-Thompson ML, Atkinson MA, Butler AE et al (2013) The diagnosis of insulitis in human type 1 diabetes. Diabetologia 56:2541-2543

21. Pipeleers D, Ling Z (1992) Pancreatic beta cells in insulindependent diabetes. Diabetes Metab Rev 8:209-227

22. In't Veld P (2011) Insulitis in human type 1 diabetes: the quest for an elusive lesion. Islets 3:131-138

23. In't Veld P, Lievens D, De Grijse J et al (2007) Screening for insulitis in adult autoantibody-positive organ donors. Diabetes 56: 2400-2404

24. Gepts W, De Mey J (1978) Islet cell survival determined by morphology. An immunocytochemical study of the islets of Langerhans in juvenile diabetes mellitus. Diabetes 27(Suppl 1):251-261

25. Gianani R, Campbell-Thompson M, Sarkar SA et al (2010) Dimorphic histopathology of long-standing childhood-onset diabetes. Diabetologia 53:690-698

26. Schneider D, Von Herrath M (2014) Studies of the cytokine milieu of pancreatic islets and its role in the ontology of immune mediated diabetes. In: Annual Conference of the Network for Pancreatic Organ Donors, nPOD, Jacksonville (Abstract)

27. Fonseca V, Berger LA, Beckett AG, Dandona P (1985) Size of pancreas in diabetes mellitus: a study based on ultrasound. Br Med J (Clin Res Ed) 291:1240-1241

28. Campbell-Thompson M, Wasserfall C, Montgomery EL, Atkinson MA, Kaddis JS (2012) Pancreas organ weight in individuals with disease-associated autoantibodies at risk for type 1 diabetes. JAMA 308:2337-2339

29. Willcox A, Richardson SJ, Bone AJ, Foulis AK, Morgan NG (2009) Analysis of islet inflammation in human type 1 diabetes. Clin Exp Immunol 155:173-181

30. Atkinson MA, Eisenbarth GS (2001) Type 1 diabetes: new perspectives on disease pathogenesis and treatment. Lancet 358:221-229

31. Ziegler AG, Nepom GT (2010) Prediction and pathogenesis in type 1 diabetes. Immunity 32:468-478

32. von Herrath MG, Fujinami RS, Whitton JL (2003) Microorganisms and autoimmunity: making the barren field fertile? Nat Rev Microbiol $1: 151-157$

33. von Herrath M, Sanda S, Herold K (2007) Type 1 diabetes as a relapsing-remitting disease? Nat Rev Immunol 7:988-994

34. Fujinami RS, von Herrath MG, Christen U, Whitton JL (2006) Molecular mimicry, bystander activation, or viral persistence: infections and autoimmune disease. Clin Microbiol Rev 19:80-94

35. Skog O, Korsgren S, Melhus A, Korsgren O (2013) Revisiting the notion of type 1 diabetes being a T-cell-mediated autoimmune disease. Curr Opin Endocrinol Diabetes Obes 20:118-123

36. Jenson AB, Rosenberg HS, Notkins AL (1980) Pancreatic islet-cell damage in children with fatal viral infections. Lancet 2:354-358

37. Oikarinen M, Tauriainen S, Honkanen T et al (2008) Analysis of pancreas tissue in a child positive for islet cell antibodies. Diabetologia 51:1796-1802

38. Skog O, Korsgren O, Frisk G (2011) Modulation of innate immunity in human pancreatic islets infected with enterovirus in vitro. J Med Virol 83:658-664

39. Alidjinou EK, Sané F, Engelmann I, Hober D (2013) Serumdependent enhancement of coxsackievirus B4-induced production of IFN $\alpha$, IL- 6 and TNF $\alpha$ by peripheral blood mononuclear cells. J Mol Biol 425:5020-5031
40. Parks GD, Alexander-Miller MA Paramyxovirus activation and inhibition of innate immune responses. J Mol Biol 425: 4872-4892

41. Koma T, Huang C, Kolokoltsova OA, Brasier AR, Paessler S (2013) Innate immune response to arenaviral infection: a focus on the highly pathogenic New World hemorrhagic arenaviruses. J Mol Biol 425:4893-4903

42. Turley SJ, Lee JW, Dutton-Swain N, Mathis D, Benoist C (2005) Endocrine self and gut non-self intersect in the pancreatic lymph nodes. Proc Natl Acad Sci U S A 102:17729-17733

43. Akatsuka H, Yano Y, Gabazza EC et al (2009) A case of fulminant type 1 diabetes with coxsackie $\mathrm{B} 4$ virus infection diagnosed by elevated serum levels of neutralizing antibody. Diabetes Res Clin Pract 84: e50-e 52

44. Barboni E, Manocchio I, Asdrubali G (1966) Observations on diabetes in cattle due to experimental epizootic aphthae (Preliminary note). Nuovi Ann Ig Microbiol 17:223-226 [Article in Italian]

45. Niklasson B, Heller KE, Schonecker B et al (2003) Development of type 1 diabetes in wild bank voles associated with islet autoantibodies and the novel Ljungan virus. Int J Exp Diabesity Res 4:35-44

46. Ellerman KE, Richards CA, Guberski DL, Shek WR, Like AA (1996) Kilham rat triggers T-cell-dependent autoimmune diabetes in multiple strains of rat. Diabetes 45:557-562

47. Yoon JW, London WT, Curfman BL, Brown RL, Notkins AL (1986) Coxsackie virus B4 produces transient diabetes in nonhuman primates. Diabetes 35:712-716

48. Yang C, Diiorio P, Jurczyk A, O'Sullivan-Murphy B, Urano F, Bortell R (2013) Pathological endoplasmic reticulum stress mediated by the IRE1 pathway contributes to pre-insulitic beta cell apoptosis in a virus-induced rat model of type 1 diabetes. Diabetologia $56: 2638-2646$

49. Chehadeh W, Kerr-Conte J, Pattou F et al (2000) Persistent infection of human pancreatic islets by coxsackievirus B is associated with alpha interferon synthesis in beta cells. J Virol 74:10153-10164

50. Prchal-Murphy M, Semper C, Lassnig C et al (2012) TYK2 kinase activity is required for functional type I interferon responses in vivo. PLoS One 7:e39141

51. Richer MJ, Horwitz MS (2008) Viral infections in the pathogenesis of autoimmune diseases: focus on type 1 diabetes. Front Biosci 13: $4241-4257$

52. Capua I, Mercalli A, Pizzuto MS et al (2012) Influenza A viruses grow in human pancreatic cells and cause pancreatitis and diabetes in an animal model. J Virol 87:597-610

53. Sano H, Terasaki J, Tsutsumi C, Imagawa A, Hanafusa T (2008) A case of fulminant type 1 diabetes mellitus after influenza B infection. Diabetes Res Clin Pract 79:e8-e9

54. Bonifacio E, Krumsiek J, Winkler C, Theis FJ, Ziegler AG (2013) A strategy to find gene combinations that identify children who progress rapidly to type 1 diabetes after islet autoantibody seroconversion. Acta Diabetol 51:403-411

55. Razavi R, Chan Y, Afifiyan FN et al (2006) TRPV1 ${ }^{+}$sensory neurons control beta cell stress and islet inflammation in autoimmune diabetes. Cell 127:1123-1135

56. Shen Z, He H, Wu Y, Li J (2013) Cyclosporin a inhibits rotavirus replication and restores interferon-beta signaling pathway in vitro and in vivo. PLoS One 8:e71815

57. Lakhan SE, Kirchgessner A (2010) Gut inflammation in chronic fatigue syndrome. Nutr Metab (Lond) 7:79

58. Coppieters KT, von Herrath MG (2010) Viruses and cytotoxic $\mathrm{T}$ lymphocytes in type 1 diabetes. Clin Rev Allergy Immunol 41: $169-178$

59. Vreugdenhil GR, Geluk A, Ottenhoff TH, Melchers WJ, Roep BO, Galama JM (1998) Molecular mimicry in diabetes mellitus: the homologous domain in coxsackie $\mathrm{B}$ virus protein $2 \mathrm{C}$ and islet autoantigen GAD65 is highly conserved in the coxsackie B-like 
enteroviruses and binds to the diabetes associated HLA-DR3 molecule. Diabetologia 41:40-46

60. Wucherpfennig KW, Strominger JL (1995) Molecular mimicry in T cell-mediated autoimmunity: viral peptides activate human $\mathrm{T}$ cell clones specific for myelin basic protein. Cell 80:695-705

61. Oikarinen S, Tauriainen S, Hober D et al (2014) Virus antibody survey in different european populations indicates risk association between coxsackievirus B1 and type 1 diabetes. Diabetes 63:655662

62. Laitinen OH, Honkanen H, Pakkanen O et al (2014) Coxsackievirus B1 is associated with induction of beta-cell autoimmunity that portends type 1 diabetes. Diabetes 63:446-455

63. Yoon JW, Austin M, Onodera T, Notkins AL (1979) Isolation of a virus from the pancreas of a child with diabetic ketoacidosis. N Engl J Med 300:1173-1179

64. Ramondetti F, Sacco S, Comelli M et al (2011) Type 1 diabetes and measles, mumps and rubella childhood infections within the Italian Insulin-dependent Diabetes Registry. Diabet Med 29:761-766

65. Stene LC, Oikarinen S, Hyoty H et al (2010) Enterovirus infection and progression from islet autoimmunity to type 1 diabetes: the Diabetes and Autoimmunity Study in the Young (DAISY). Diabetes 59:3174-3180

66. Sarmiento L, Frisk G, Anagandula M, Cabrera-Rode E, Roivainen M, Cilio CM (2013) Expression of innate immunity genes and damage of primary human pancreatic islets by epidemic strains of echovirus: implication for post-virus islet autoimmunity. PLoS One 8:e77850

67. Honke N, Shaabani N, Zhang DE et al (2013) Usp18 driven enforced viral replication in dendritic cells contributes to break of immunological tolerance in autoimmune diabetes. PLoS Pathog 9:e1003650

68. Minot S, Bryson A, Chehoud C, Wu GD, Lewis JD, Bushman FD (2013) Rapid evolution of the human gut virome. Proc Natl Acad Sci U S A 110:12450-12455

69. Mazmanian SK, Round JL, Kasper DL (2008) A microbial symbiosis factor prevents intestinal inflammatory disease. Nature 453: 620-625

70. Balada E, Vilardell-Tarres M, Ordi-Ros J (2010) Implication of human endogenous retroviruses in the development of autoimmune diseases. Int Rev Immunol 29:351-370

71. Schneider D, Chodaczek G, Coppieters K, Von Herrath M (2013) Antigen-specificity requirements for $\mathrm{T}$ cell invasion of pancreatic islets in a virus-induced autoimmune diabetes model. In: Annual Conference of the Federation of Clinical Immunology Societies, Boston, No. F.38 (Abstract)

72. Pane JA, Webster NL, Graham KL, Holloway G, Zufferey C, Coulson BS (2012) Rotavirus acceleration of murine type 1 diabetes is associated with a $\mathrm{T}$ helper 1-dependent specific serum antibody response and virus effects in regional lymph nodes. Diabetologia $56: 573-582$

73. Tonegawa S (1983) Somatic generation of antibody diversity. Nature 302:575-581

74. Goodnow CC, Sprent J, Fazekas de St Groth B, Vinuesa CG (2005) Cellular and genetic mechanisms of self tolerance and autoimmunity. Nature 435:590-597

75. Zandman-Goddard G, Shoenfeld Y (2002) HIV and autoimmunity. Autoimmun Rev 1:329-337

76. Niller HH, Wolf H, Minarovits J (2008) Regulation and dysregulation of Epstein-Barr virus latency: implications for the development of autoimmune diseases. Autoimmunity 41 : 298-328

77. Vento S, McFarlane BM, McSorley CG et al (1988) Liver autoreactivity in acute virus A, B and non-A, non-B hepatitis. J Clin Lab Immunol 25:1-7

78. Cassani F, Cataleta M, Valentini P et al (1997) Serum autoantibodies in chronic hepatitis C: comparison with autoimmune hepatitis and impact on the disease profile. Hepatology 26:561-566

79. Ahmed R, Byrne JA, Oldstone MB (1984) Virus specificity of cytotoxic $\mathrm{T}$ lymphocytes generated during acute lymphocytic choriomeningitis virus infection: role of the $\mathrm{H}-2$ region in determining cross-reactivity for different lymphocytic choriomeningitis virus strains. J Virol 51:34-41

80. Hunziker L, Recher M, Macpherson AJ et al (2003) Hypergammaglobulinemia and autoantibody induction mechanisms in viral infections. Nat Immunol 4:343-349

81. Mouquet H, Nussenzweig MC (2011) Polyreactive antibodies in adaptive immune responses to viruses. Cell Mol Life Sci 69:14351445

82. Filippi CM, Estes EA, Oldham JE, von Herrath MG (2009) Immunoregulatory mechanisms triggered by viral infections protect from type 1 diabetes in mice. J Clin Invest 119:1515-1523

83. Filippi CM, Ehrhardt K, Estes EA, Larsson P, Oldham JE, von Herrath MG (2011) TLR2 signaling improves immunoregulation to prevent type 1 diabetes. Eur J Immunol 41:1399-1409

84. Kanno T, Kim K, Kono K, Drescher KM, Chapman NM, Tracy S (2006) Group B coxsackievirus diabetogenic phenotype correlates with replication efficiency. J Virol 80:5637-5643

85. Willcox A, Richardson SJ, Bone AJ, Foulis AK, Morgan NG (2011) Immunohistochemical analysis of the relationship between islet cell proliferation and the production of the enteroviral capsid protein, VP1, in the islets of patients with recent-onset type 1 diabetes. Diabetologia 54:2417-2420

86. Hansson SF, Korsgren S, Ponten F, Korsgren O (2013) Enteroviruses and the pathogenesis of type 1 diabetes revisited: cross-reactivity of enterovirus capsid protein (VP1) antibodies with human mitochondrial proteins. J Pathol 229:719-728

87. Pugliese A, Yang M, Kusmarteva I et al (2014) The Juvenile Diabetes Research Foundation Network for Pancreatic Organ Donors with Diabetes (nPOD) Program: goals, operational model and emerging findings. Pediatr Diabetes 15:1-9

88. Korsgren S, Molin Y, Salmela K, Lundgren T, Melhus A, Korsgren O (2012) On the etiology of type 1 diabetes: a new animal model signifying a decisive role for bacteria eliciting an adverse innate immunity response. Am J Pathol 181:1735-1748

89. Temajo NO, Howard N (2014) The mosaic of environment involvement in autoimmunity: the abrogation of viral latency by stress, a non-infectious environmental agent, is an intrinsic prerequisite prelude before viruses can rank as infectious environmental agents that trigger autoimmune diseases. Autoimmun Rev 13:653-658

90. Rasmussen T, Witso E, Tapia G, Stene LC, Ronningen KS (2011) Self-reported lower respiratory tract infections and development of islet autoimmunity in children with the type 1 diabetes highrisk HLA genotype: the MIDIA study. Diabetes Metab Res Rev 27: 834-837

91. Beyerlein A, Wehweck F, Ziegler AG, Pflueger M (2013) Respiratory infections in early life and the development of islet autoimmunity in children at increased type 1 diabetes risk: evidence from the BABYDIET study. JAMA Pediatr 167:800-807

92. Gale EA (2008) Congenital rubella: citation virus or viral cause of type 1 diabetes? Diabetologia 51:1559-1566

93. Viskari H, Paronen J, Keskinen P et al (2003) Humoral beta-cell autoimmunity is rare in patients with the congenital rubella syndrome. Clin Exp Immunol 133:378-383

94. Green J, Casabonne D, Newton R (2004) Coxsackie B virus serology and type 1 diabetes mellitus: a systematic review of published case-control studies. Diabet Med 21:507-514

95. Tapia G, Cinek O, Rasmussen T et al (2010) Human enterovirus RNA in monthly fecal samples and islet autoimmunity in Norwegian children with high genetic risk for type 1 diabetes: the MIDIA study. Diabetes Care 34:151-155 
96. Yeung WC, Rawlinson WD, Craig ME (2011) Enterovirus infection and type 1 diabetes mellitus: systematic review and meta-analysis of observational molecular studies. BMJ 342:d35

97. Salur L, Oikarinen S, Tauriainen S, Mandel M, Hyoty H, Uibo R (2011) Enterovirus infections in young infants: are children still protected by maternal antibodies? Hum Vaccin 7:966-971

98. Oikarinen M, Tauriainen S, Oikarinen S et al (2012) Type 1 diabetes is associated with enterovirus infection in gut mucosa. Diabetes 61: $687-691$

99. Mercalli A, Lampasona V, Klingel K et al (2012) No evidence of enteroviruses in the intestine of patients with type 1 diabetes. Diabetologia 55:2479-2488

100. Viskari HR, Koskela P, Lonnrot M et al (2000) Can enterovirus infections explain the increasing incidence of type 1 diabetes? Diabetes Care 23:414-416

101. Roivainen M, Ylipaasto P, Savolainen C, Galama J, Hovi T, Otonkoski T (2002) Functional impairment and killing of human beta cells by enteroviruses: the capacity is shared by a wide range of serotypes, but the extent is a characteristic of individual virus strains. Diabetologia 45:693-702

102. Viskari H, Ludvigsson J, Uibo R et al (2004) Relationship between the incidence of type 1 diabetes and enterovirus infections in different European populations: results from the EPIVIR project. J Med Virol 72:610-617

103. Viskari H, Ludvigsson J, Uibo R et al (2005) Relationship between the incidence of type 1 diabetes and maternal enterovirus antibodies: time trends and geographical variation. Diabetologia 48:1280-1287

104. Richardson SJ, Willcox A, Bone AJ, Foulis AK, Morgan NG (2009) The prevalence of enteroviral capsid protein vp1 immunostaining in pancreatic islets in human type 1 diabetes. Diabetologia 52:11431151

105. Gamble DR, Taylor KW, Cumming H (1973) Coxsackie viruses and diabetes mellitus. Br Med J 4:260-262

106. Gamble DR, Kinsley ML, FitzGerald MG, Bolton R, Taylor KW (1969) Viral antibodies in diabetes mellitus. Br Med J 3: 627-630

107. Dotta F, Censini S, van Halteren AG et al (2007) Coxsackie B4 virus infection of beta cells and natural killer cell insulitis in recentonset type 1 diabetic patients. Proc Natl Acad Sci U S A 104:51155120

108. Cabrera-Rode E, Sarmiento L, Tiberti C et al (2003) Type 1 diabetes islet associated antibodies in subjects infected by echovirus 16 . Diabetologia 46:1348-1353 